Christin Emrich

Nachhaltigkeits-Marketing-Management 



\section{Christin Emrich}

NachhaltigkeitsMarketing-

Management

Konzept, Strategien, Beispiele 
ISBN 978-3-11-037687-6

e-ISBN (PDF) 978-3-11-037630-2

e-ISBN (EPUB) 978-3-11-039870-0

Library of Congress Cataloging-in-Publication Data

A CIP catalog record for this book has been applied for at the Library of Congress.

\section{Bibliografische Information der Deutschen Nationalbibliothek}

Die Deutsche Nationalbibliothek verzeichnet diese Publikation in der Deutschen Nationalbibliografie; detaillierte bibliografische Daten sind im Internet über

http://dnb.dnb.de abrufbar.

(C) 2015 Walter de Gruyter GmbH, Berlin/Boston Coverabbildung: gianliguori/iStock/thinkstock Druck und Bindung: CPI books GmbH, Leck @ Gedruckt auf säurefreiem Papier Printed in Germany

www.degruyter.com 